Scientił studia, São Paulo, v. 2, n. 3, p. 395-4,13, 2004

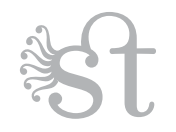

\title{
Entrevista com Jean-Pierre Berlan
}

\author{
por Isabel Loureiro e Marcos Barbosa de Oliveira \\ durante o Fórum Social Mundial de 2003 (Porto Alegre)*
}

Jean-Pierre Berlan formou-se engenheiro agrônomo pelo Institut National Agronomique, Paris, fez o Doutorado de Estado em Ciências Econômicas, e é diretor de pesquisa do INRA-CTESI (Institut National de la Recherche Agronomique-Changement Technique et Evolution des Systèmes d'Innovation), Montpellier. Seus trabalhos tratam da transformação da agricultura no século $\mathrm{xx}$, e do papel da genética agrícola. É autor de La guerre au vivant: OGM et autres mystifications scientifiques, ${ }^{1}$ e de inúmeros artigos, entre os quais "Political economy of agricultural genetics", "La faim dans le monde, les OGM et l'Académie des Sciences”, 3 e, em colaboração com Richard Lewontin, "Plant breeders' rigths and the patenting of life forms", 4 "The political economy of agricultural research", 5 e "La menace du complexe génético-industriel". 6

Gostaríamos em primeiro lugar de ouvi-lo sobre sua formação intelectual, e seus temas de pesquisa.

Sou engenheiro agrônomo, com doutorado em economia. Meu trabalho versa sobre a transformação da agricultura, quer dizer, a liquidação do campesinato e a sua substituição por um sistema agro-industrial, e sobre o papel das ciências e das técnicas nessa transformação. Faz 20 anos comecei a me interessar pela indústria de sementes, e desde esse momento passei à história da genética e à história das práticas de seleção. Trabalhei um pouco com os animais (um domínio que permanece por explorar) e sobretudo com a história da seleção das plantas. E cheguei a conclusões diametralmente opostas ao que os selecionadores e geneticistas assumem e ensinam.

\footnotetext{
* Entrevista revista e atualizada pelo entrevistado em agosto de 2004, e traduzida e editada pelos entrevistadores, com a colaboração de Hugh Lacey.

1 Marselha, Agone, 2001.

2 In R. Singh, K. Krimbas, D. Paul e P. Beatty (orgs.), Thinking about evolution: historical, philosophical and political perspectives (Cambridge, Cambridge University Press, 2001).

3 L'Ecologiste, n. 7, 2002.

4 Nature, 322, p. $785^{-8}, 1986$.

5 In C. R. Carroll, J. H.Vandermeer e P. M. Rosset (orgs.), Agroecology (Nova York, McGraw Hill, 1990).

6 Le Monde Diplomatique, dezembro 1998.
} 
Em particular, re-analisei a técnica emblemática da pesquisa agronômica no século $\mathrm{xx}$, a das chamadas "variedades híbridas" de milho, e mostrei que, longe de ser um triunfo da filantropia genética, ela era dirigida contra os agricultores e, de maneira geral, contra o público. O selecionador deve lucrar com sua atividade. As plantas e os animais se reproduzem gratuitamente nos campos do agricultor. É esta contradição que precisa ser resolvida. As "variedades híbridas" de milho têm a propriedade miraculosa - para o selecionador e produtor de sementes! - de não poder se reproduzir no campo do agricultor, que é forçado a comprar sementes todos os anos. É o primeiro Terminator.

Passemos aos Organismos Geneticamente Modificados, questão muito complexa. Há um argumento dos seus defensores que diz que eles aumentam a produtividade das culturas. Você concorda com isso?

Não, é uma mentira. O rendimento da soja assim como do milho "OGM", que constituem 95\% das culturas ditas "OGM", é menor do que o das plantas convencionais. A razão é simples: uma parte da energia da planta é usada para lutar contra o herbicida que se aplica ou para produzir uma toxina inseticida. A maioria dos "OGM" cultivados hoje são tolerantes ao Roundup - trata-se de plantas ditas Roundup Ready ou RR -, o que permite à Monsanto, proprietária da marca Roundup, aumentar o mercado de seu herbicida mais importante. Até 1996-97, ele não podia ser utilizado na soja. A Monsanto aumenta a área tratada com o Roundup e assim o mercado do
Roundup, como mostra o caso brasileiro. E sobretudo - o que a Monsanto não diz - essas plantas RR permitem prolongar as vantagens da patente do Roundup, ou mais precisamente do glifosato, a molécula herbicida do Roundup cuja patente expirou formalmente na maior parte dos países do mundo no final dos anos 1990. O glifosato foi descoberto acidentalmente no fim dos anos 40 por um químico suíço e não pela Monsanto. O agricultor que comete a besteira de comprar sementes tolerantes ao Roundup deve, por contrato, comprar glifosato da marca Roundup que custa três ou quatro vezes mais que o glifosato genérico!

A soja tolerante ao Roundup traz, é preciso enfatizar, um conforto provisório para os grandes agricultores, facilitando a retirada das ervas "daninhas". Eles podem tratar as culturas usando avião e um único herbicida, o que lhes dá uma vantagem concorrencial sobre os pequenos e médios agricultores, que eles eliminam. A enorme desigualdade na repartição de terras no Brasil explica o desenvolvimento ilegal das culturas de soja transgênica tolerante ao glifosato-Roundup nas grandes propriedades. Mas esses grandes agricultores, cavalos de Tróia de Monsanto, não se dão conta de que põem a corda no pescoço. A partir do momento em que se generaliza a utilização do Roundup - o que é o caso - as plantas adventícias, incorretamente chamadas de ervas "daninhas" para justificar sua erradicação, vão se tornar resistentes ao Roundup. Será preciso utilizar quantidades crescentes de Roundup. É o que começa a acontecer nos Estados Unidos. Será preciso então utilizar misturas de herbicidas para controlar as ervas "daninhas". Mas como a 
Monsanto teve o desplante de patentear a idéia (!) de misturar os herbicidas - o que os agricultores faziam habitualmente - essas misturas serão o monopólio da Monsanto. Que por elas fará pagar a um preço exorbitante.

Os transgênicos representam também um problema para a saúde?

Um dos segredos mais bem guardados a respeito dos "Organismos Geneticamente Modificados" é a instabilidade das construções genéticas. Elas têm a tendência a ser re-arranjadas pelas plantas no decorrer de sucessivas gerações, sem que se tenha a mínima idéia do que isso pode produzir.

A transgenia consiste em injetar de maneira forçada e violenta construções genéticas artificiais, quimeras genéticas, em células vegetais. Para se compreender a lógica e a ausência surpreendente de estudos de toxicologia sobre os riscos que ela introduz é preciso fazer um desvio histórico e teórico. Em 1958, Francis Crick (o co-descobridor da estrutura de dupla hélice do DNA) formula a "hipótese seqüencial" (a um gene corresponde uma proteína) e o "dogma central da biologia molecular" (a transferência da informação genética faz-se unicamente do DNA para as proteínas). Toda transferência proteína $\Rightarrow$ DNA, ou proteína $\Rightarrow$ proteína, "abalaria”, escreve ele em 1970, "as bases da biologia molecular". Essas simplificações drásticas eram necessárias para decodificar o código genético do qual, na época, se ignorava tudo. ${ }^{7}$ Mas com o triunfo que foi a decodificação, essas hipóteses de trabalho tornaram-se propriedades reaisdo ser vivo. Então construiu-se uma ideologia em torno do DNA, molécula fabricando a vida (as proteínas) e capaz de auto-reprodução. A dupla hélice substituiu o cogumelo atômico como ícone da nossa modernidade. Mas tudo isso é falso e todo biólogo sabe disso, mesmo que evite reconhecê-lo publicamente.

Desde os anos 1970, as provas dessas transferências começam a se acumular, mas sem provocar o abalo anunciado por Crick. Aideologia do DNA serve poderosamente aos desígnios dos industriais: o ser vivo é reduzido a um mecanismo; a transferência de um gene permite obter a proteína ou a função correspondente. Inútil fazer testes de toxidade ou preocupar-se com o que se passa em seguida no genoma! As pressões dos industriais e de outros investidores proibiram todo um domínio de pesquisa científica, tanto mais facilmente que os próprios cientistas se tornaram empresários fundadores de empresas, ou, com a ajuda de contratos, mercenários a serviço de lucros rápidos e não do progresso dos conhecimentos. Em 2000, a "decodificação" do genoma humano confirma o que os biólogos silenciam e querem ignorar: que nossa espécie tem de três a dez vezes mais proteínas que genes. Quanto ao dogma central, está morto desde quando se sabe que as proteínas intervêm na leitura do DNA. As manipulações genéticas e os "OGM" não têm

7 Cf., p. ex., B. Commoner, Unravelling the DNA myth: the spurious foundation of genetic engineering (Harper's Magazine, fev. 2002) e R. Lewontin, The triple helix: gene, organism, and environment (Cambridge, Harvard University Press, 2002). 
portanto fundamento científico. São puras técnicas que, como de costume, estão décadas à frente dos conhecimentos científicos. E como a difusão de suas quimeras genéticas é inevitável, os "biotécnicos" estão em vias de transformar nosso planeta em laboratório.

Um segundo risco provém do tipo de "OGM" comercializado. No caso das plantas tolerantes aos herbicidas, o herbicida deve entrar na planta para agir. Para que faça isso, utilizam-se moléculas que facilitam a penetração do herbicida. Esse herbicida não é destruído na planta, mas é, na maioria dos casos, simplesmente neutralizado pela superexpressão [surexpression] de uma enzima. O herbicida entra assim na cadeia alimentar, o que não acontecia antes uma vez que até agora as plantas tratadas morriam.

O outro tipo de construção genética em circulação consiste nas plantas chamadas de maneira mentirosa "Bt resistentes a" este ou aquele inseto destruidor. O vocabulário é bem achado: todo mundo acredita que se trata de métodos ecológicos de luta. A realidade é exatamente a oposta. Basta chamar as plantas pelo nome: são plantas inseticidas. Esse inseticida entra também na cadeia alimentar. $\mathrm{O}$ que de imediato põe no mínimo duas questões que o termo "planta resistente a" permitia evitar. A proteína inseticida produzida pela planta é a mesma que a proteína produzida pelo famoso Bacillus thuringiensis (Bt) que vive no solo? Não. O gene que intervém na fabricação dessa proteína foi profundamente modificado e a própria proteína é profundamente modificada. O termo "resistente a" permite assim introduzir sem teste um novo pesticida no meio-ambiente e na cadeia alimentar. E a segunda questão: que quantidade dessa toxina é largada no meio-ambiente, sabendo que foi produzida por cada célula de uma planta "geneticamente modificada"? Meus colegas do INRA, a quem coloquei a questão, foram incapazes de me responder. Talvez não tivessem pensado nisso, já que pela magia das palavras "resistente a" o problema não se punha.

Segundo uma "estimativa grosseira" de Charles Benbrook, ${ }^{8}$ antigo secretário da seção de Agronomia da Academia Nacional de Ciências dos Estados Unidos, um campo de milho Bt, ou de algodão Bt, produziria entre 10 mil e 100 mil vezes a quantidade de toxinas Bt que um agricultor utilizando de maneira intensiva os tratamentos Bt! Como se vê, estamos em plena ecologia! E uma parte dessas toxinas entra na cadeia alimentar. Pode-se esperar que elas modifiquem profundamente a flora digestiva e a dos solos. Mas simplesmente não se fazem estudos, o que permite confundir a ausência de prova de toxidade dos "OGM" com a prova de sua ausência.

Como eu disse um dia a uma rádio italiana: os camponeses e o povo italiano nos deram esse prato sublime de simplicidade, a pasta al pesto. As transnacionais agrotóxicas o substituem, sinal dos tempos, pela pasta al pesticida (risos).

Os defensores dos OGM vendem sua técnica dizendo que ela é extremamente moderna. Sabemos que vocênão concorda com isso. Será que você poderia nos explicar seu ponto de vista? 
Quando eu era aluno na Escola de Agronomia no início dos anos 6o, era o começo dos pesticidas e todo mundo acreditava que os pesticidas e os adubos iam resolver todos os problemas e que, definitivamente, a agronomia, essa arte da complexidade, dependia do obscurantismo. Ensinava-se aos futuros engenheiros que o trigo na região parisiense devia ser tratado com tal produto em tal data, tal outro produto em tal outra data etc. Depois de algum tempo parei de assistir aos cursos porque me parecia absurdo fazer um tratamento sem ter certeza se era ou não necessário. Ora, com as plantas inseticidas, o que se faz senão tratá-las previamente? Em 1998 estive em Illinois, no coração do cinturão do milho-soja, não havia sombra de piralídeo de milho no horizonte. Os agricultores que haviam semeado milho "resistente ao" piralídeo tinham feito um tratamento - maciço ainda por cima! - para nada. É evidente a estupidez agronômica dessas técnicas que dependem de concepções mecanicistas obsoletas e cujas conseqüências são catastróficas para os ecosistemas e para a saúde pública.

Mas e quanto à modernidade dessas técnicas?

A modernidade dos "OGM"... É preciso voltar à história das práticas de seleção para compreender que, na realidade, estamos no mais total passadismo. De há dois séculos para cá o selecionador se esforça para substituir variedades - segundo o dicionário, conjuntos feitos de elementos diferentes; diversidade; contrário da uniformidade - por um modelo ou um genótipo único. Para fazer essa operação, ele deve produzir esse genótipo único em tantos exemplares quantos são necessários, quer dizer, ele deve clonar. Um clone é uma população de organismos geneticamente idênticos ou quase.

Mais precisamente, o selecionador se esforça para substituir uma variedade pelo melhor dos clones que conseguiu extrair. Seu trabalho consiste portanto em fazer clones, depois em selecionar o melhor para substituir a variedade. Dolly não é, desse ponto de vista, senão a extensão aos mamíferos do que se faz com as plantas já há dois séculos. Do ponto de vista dos princípios, Dolly é uma espécie de máquina a vapor das mais primitivas. Estamos do lado oposto do que deveria ser a modernidade agronômica.

Essa seleção-clonagem precede de um século a genética, o que sugere que os vínculos entre a seleção e a genética são no mínimo distantes, senão quase-inexistentes ou, mais precisamente, que esses vínculos são de natureza ideológica: a genética serve de camuflagem ideológico-científica à dinâmica da industrialização e da privatização do ser vivo. ${ }^{9}$ Este fato desagrada muito aos meus colegas, mas o que fazer se eles são vítimas de suas ilusões cientificistas? É irônico vê-los exigir alto e bom som o direito (legítimo) ao erro, em geral para seus colegas da micro-disciplina vizinha, evitando reconhecer que se enganaram quando tudo prova que é o caso! 
Três razões explicam essa devoção à clonagem. Os nobres agricultores ingleses - os farmers ricardianos - aplicam ao ser vivo os princípios de homogeneidade e de estabilidade dos produtos em série da revolução industrial. Logicamente, seu método é irrefutável. Bio-logicamente, é outra coisa, mas só recentemente os biólogos (os que sobraram) adquiriram novamente consciência do caráter mortífero da monocultura e da uniformidade industriais e do papel vital da biodiversidade. E, por fim, diferentemente de uma variedade, um clone se presta ao direito de propriedade. Uma variedade, por ser heterogênea e estar em constante evolução não pode ser objeto de um direito de propriedade. Um clone é homogêneo e estável. Esta espécie de morto-vivo pode pois ser minuciosamente descrito para ser distinguido dos outros clones. A Distinção, a Homogeneidade, e a Estabilidade fundamentam a proteção do selecionador pelo certificado de obtenção varietal [certificat d'obtention variétale] que protege suas "variedades" da "pirataria" pelos concorrentes. Essa proteção, veremos, se mostrou insuficiente para as transnacionais agrotóxicas que tomaram posse da indústria das sementes no decurso dos últimos 10/15 anos, pois ela não proíbe a prática fundadora da agricultura, semear o grão colhido.

É preciso dizer uma palavra sobre a invenção da seleção clonagem. Ela é anunciada pela antiga prática da mergulhia de certas plantas e da enxertia das árvores frutíferas. A revolução industrial a generaliza. Os nobres agricultores ingleses - esses grandes aperfeiçoadores - constatam no início do século XIX que as plantas de trigo, cevada, aveia, conservam suas características individuais de uma geração à seguinte. Eles não sabem por que, mas pouco importa. Em 1836, um dentre eles, John Le Couteur, codifica a prática de seus colegas: "Já que cultivamos variedades de plantas e que cada uma das plantas da mistura conserva suas características individuais", raciocina ele, “vou 'isolar' as plantas que me parecem mais interessantes para reproduzilas e multiplicá-las individualmente a partir de um único grão ou de uma única espiga. Vou testar "pure sorts" - os clones - correspondentes para substituir a variedade pelo melhor clone”. Le Couteur, espírito científico preciso embora amador, utiliza o termo "pure sort", "pura cepa", que indica precisamente que ele substitui a variedade por uma uniformidade ou homogeneidade. ${ }^{10}$ Infelizmente, seus sucessores, cientistas profissionais, amigos do rigor e da precisão, utilizam o termo "variedade" para designar exatamente o oposto! Não surpreende de modo algum que eles se calem assim sobre o essencial.

Sabemos agora que a característica do mundo vivo é sua diversidade. Sabemos também que essa diversidade é produtiva em si. ${ }^{\mathbf{1 1}}$ Há uma contradição entre a dinâmica econômica dessa biologia aplicada à agricultura e à

$10 \mathrm{Cf}$. John le Couter, On the varieties, properties, and classification of wheat (Londres, W.J. Johnson, 1836).

11 Cf. D. Tilman et al., Diversity and productivity in a long-term grassland experiment (Science, 294, 2002, p. 84,3-5). Esses pesquisadores mostram, p.ex., que lavouras com dezesseis espécies produziram uma biomassa total superior em $42 \%$ com relação à espécie mais produtiva em monocultura. 
alimentação, entre essa dinâmica de padronização, uniformização, homogeneização, industrialização da agricultura e o ser vivo. $\mathrm{O}$ que o termo "variedade" permite esconder. A uniformidade industrial é mortífera. No futuro, será preciso re-aprender a utilizar a diversidade. Esse é um primeiro ponto importante para os agrônomos.

Voltemos à confiscação do ser vivo. Ela está em germe na técnica da seleção clonagem, mas será preciso esperar a segunda metade do século XIx para que surja no domínio vegetal a contradição entre vida e lucro. Os primeiros selecionadores profissionais que aparecem na Inglaterra nesse momento se apercebem, como homens de negócios, que não terão mercado enquanto o grão colhido pelos camponeses for também a semente do ano seguinte. E eles começam imediatamente a "guerra ao ser vivo", ${ }^{\mathbf{2}}$ a eliminação da concorrência desleal que lhes é feita pelas plantas e animais ao se reproduzirem e multiplicarem nas terras dos camponeses.

Essa guerra ao ser vivo levou um século e meio e acabou com uma vitória técnica definitiva com a patente "controle da expressão dos genes" depositada conjuntamente pela pesquisa pública (!!) estadunidense e uma firma privada em 1998. Essa técnica de transgenia foi batizada Terminator por seus oponentes, e permite fazer sementes que dão plantas normais na aparência, que dão flores normais até o momento em que o grão se forma. Nesse momento a planta mata o germe do grão. $\mathrm{O}$ agricultor colhe um grão estéril.
Essa ignomínia criminosa é o maior triunfo da biologia aplicada de há 150 anos para cá, é o triunfo da lei do lucro sobre a lei da vida.

Esse triunfo genético foi uma derrota política na medida em que revelou o segredo mais bem guardado da história da seleção. $\mathrm{O}$ mundo inteiro, os camponeses em particular, puderam dar-se conta do caráter profundamente mortífero de nossa sociedade, já que ela tem como objetivo esterilizar o ser vivo. Ela precisa separar, por qualquer meio, biológico, técnico, legal, regulamentar, a produção que fica nas mãos dos camponeses da reprodução que vai se tornar monopólio do capital.

Você falou do "segredo mais bem guardado" da genética agrícola. Por que?

Na verdade, o primeiro Terminator retrocede ao começo do século $\mathrm{xx}$, mas os geneticistas haviam tomado o maior cuidado para maquiar essa expropriação em melhoramento. Precisamos nos deter um pouco nessa técnica emblemática da pesquisa agronômica no século xx, nas "variedades híbridas" de milho, "símbolo da agricultura americana" como declarou orgulhosamente um dia um secretário adjunto da agricultura. Com efeito um símbolo... Diferentemente do trigo, da cevada e da aveia, uma planta de milho é o resultado de um cruzamento de duas plantas diferentes. As flores com efeito estão separadas e o vento e os insetos transportam o pólen das flores macho situadas no alto da planta para as flores fêmeas das plantas vizinhas (até

12 Gf. J.-P. Berlan (org.), La guerre au vivant: Ogm et autres mystifications scientifiques (Marselha, Agone, 2002). 
muitas centenas de metros) situadas no caule. Assim sendo, uma planta de milho não conserva seus caracteres de uma geração a outra. Vê-se o interesse que há em aplicar a seleção clonagem ao milho. $\mathrm{O}$ clone de milho perde na terra do camponês o ou os caracteres (o alto rendimento, p. ex.) que o haviam levado a comprar as sementes.

No começo do século xx, biólogos estadunidenses, com base na redescoberta das leis de Mendel, se dão conta de que podem fabricar clones de milho. ${ }^{\mathbf{1 3}}$ É certamente muito demorado, muito complicado, muito caro, e por razões que não posso desenvolver aqui, essa técnica está votada ao fracasso no que concerne o melhoramento do milho. Mas ela faz da reprodução do milho o privilégio do selecionador. Ela cria uma nova fonte de lucro. É o que importa. O que é espantoso nesta história é a cegueira dos geneticistas e selecionadores (estas duas disciplinas têm tendência a fundir-se embora não tenham muito que ver uma com a outra) supostamente "públicos" - na realidade são pesquisadores do Estado - que, em nome da ciência, se obstinam em fazer triunfar essa técnica de expropriação e têm êxito depois de mais de um quarto de século de esforços.

Mas esses clonadores do Estado tomaram o maior cuidado para mistificar essa expropriação mistificando-se a si mesmos. $\mathrm{O}$ vocabulário representa um papel-chave nesse assunto. Em vez de dizer que substituíam variedades livres (que o agricultor pode semear novamente) por clones cativos (pertencentes ao selecionador), eles afirmaram ter substituído variedades por "variedades híbridas" ou "híbridos"! O hibridismo dessas pretensas "variedades" torna-se doravante o que as caracteriza. E há um século os geneticistas glosam (evidentemente em vão) um fenômeno genético misterioso, a "heterose" devida ao hibridismo do milho! ${ }^{\mathbf{1 4}}$

No entanto, um pouco de reflexão teria mostrado o absurdo de invocar o hibridismo do milho para justificar a sua clonagem. Como já disse, o trabalho do selecionador consiste em extrair clones de uma variedade para selecionar o melhor e substituir a variedade. Conseqüentemente esses clones não são nem mais nem menos "híbridos" que qualquer outra planta da variedade. Ninguém fala do hibridismo de Dolly. Que esses clones sejam ou não híbridos não tem qualquer pertinência para o trabalho do selecionador. O discurso genético sobre o hibridismo do milho tem por função ocultar a realidade da expropriação. É uma ideologia.

O termo "variedade híbrida" é uma dupla mentira. Lidamos com um clone, o contrário de uma variedade. E o termo "híbrido" não tem nenhuma pertinência uma vez que o clone não é nem mais nem menos "híbrido" que qualquer planta de milho. O que caracteriza e distingue um clone das "variedades" de milho, é que esses clones não podem ser pro-

13 Cf. G.H. Shull, "The composition of a field of maize" (American Breeders Association, 4: 296-3o1) e "A pure-line method in corn breeding" (American Breeders Association, 5:51-59).

14. CIMMYT, Book of abstracts: the genetics and exploitation of heterosis in crops - an international symposium (México, 1997). Cf. pp. 4, 34, 108, 112, 170, 174, 350, onde os autores deploram o caráter inexplicável da heterose. 
duzidos senão pelo selecionador e só por ele. São cativos. É o primeiro Terminator. É melhor não gritar isso aos quatro ventos!

Quais são as conseqüencias desse primeiro Terminator?

Lucros fabulosos, inauditos. Os clones cativos de milho são o coração da indústria de sementes mundial. Na França, atualmente, se o agricultor pudesse semear o grão colhido isso lhe custaria o preço do grão mais alguns custos de preparação. Na França, os agricultores semeiam por volta de $15 \mathrm{~kg} / \mathrm{hectare}$. As sementes dos clones cativos custam cerca de cem vezes mais. Esse é o milagre das pretensas "variedades híbridas" de milho! A tarefa da pesquisa pública, na França-e no Brasil - seria fornecer variedades livres aos agricultores, o que, em todo caso, ela evita fazer pelo menos na França. Mas não se pode ter contratos com os produtores de sementes de milho e fazer variedades livres!

Olhemos as coisas do ponto de vista de um biólogo, de um naturalista, para termos idéia do poder da ideologia científica. Os geneticistas conseguiram que todo mundo acreditasse e que eles mesmos acreditassem que para melhorar o milho era preciso de algum modo esterilizá-lo! No meu modo de ver, isso mostra que a biologia reducionista moderna perdeu todo sentido da vida. Definitivamente, os geneticistas servem-nos, sob um disfarce científico, a velha fábula da harmonia social: camponeses e selecionadores, expropriados e expropriadores têm os mesmos interesses!

Um último ponto. Eu disse que a seleção clonagem não permitia melhorar o milho.
Ora, desde a guerra o rendimento do milho foi multiplicado por 4, na França, nos Estados Unidos e em outros lugares, e esses ganhos são concomitantes com a introdução das "variedades híbridas". Isso significa que o hibridismo é a causa desses ganhos. É isso que toma o lugar do raciocínio científico há 70 anos. Não é porque cada indivíduo observa a rotação do sol em volta da terra que é assim que as coisas acontecem. É fácil entender que se melhoramos as variedades por seleção, tiramos por acaso, dessas variedades melhoradas, clones que são eles mesmos melhorados. É precisamente o que fizeram os selecionadores. Os ganhos de rendimento não têm portanto nada que ver com os mistérios do hibridismo. Eles se explicam pela seleção.

Nas suas intervenções você se refere com freqüência ao peso ideológico das palavras. Você poderia expor sua idéia?

Sim... as palavras importam. Os termos utilizados contribuem para definir a realidade. Eles são como a objetiva de um microscópio que decide o que se pode ver e portanto o que se pode fazer. Numa sociedade de comunicação de massa, as palavras não são mais criadas pelas interações quotidianas de pessoas que se encontram, se falam e inventam os termos que designam as novas realidades. Agora as palavras, os conceitos que elas recobrem vêm do alto, elas são difundidas se não criadas pelo sistema de comunicação de massa. São armas a serviço dos interesses políticoeconômicos. Em disciplinas aplicadas como a biologia onde os interesses econômicos são imediatos e consideráveis, há todas as opor- 
tunidades para que as palavras sirvam a esses interesses, para que tenham conseqüentemente uma função ideológica de ilusão mais que de conhecimento.

Em relação a isso, os camponeses dos Estados Unidos haviam batizado de milho mula esse milho revolucionário pretensamente "híbrido". A mula é estéril. Diferentemente dos geneticistas e selecionadores e de outros cientistas eles tinham compreendido muito bem a vigarice de que eram vítimas.

Mas o governo americano tinha decidido em 1922 que o método de seleção utilizado seria a seleção clonagem batizada "hibridação". 15 anos mais tarde, depois de um esforço maciço de seleção, os clonadores de Estado conseguem (graças ao poder das ciências e das técnicas modernas) extrair clones superiores das variedades cultivadas pelos camponeses. A partir de então os ganhos de rendimento, os milhões de toneladas suplementares de produção foram apresentados como prova de que a escolha política de "terminatorizar" o milho era a boa coisa! O hibridismo do milho é a causa do sucesso! A mistificação tornou-se impenetrável. No entanto, a seleção teria permitido ganhos de rendimento mais rápidos - mas sem lucro para o selecionador. Sacrificou-se assim o interesse geral aos interesses privados. Digase de passagem, o mesmo processo está se repetindo com os pretensos "OGM".

Em resumo, a história começa com os Wallace, pai e filho, que decidem em 1922 que a seleção do milho nos Estados Unidos será feita pelos "híbridos". 15 O pai Wallace é o ministro da agricultura do governo Harding. Ele toma essa decisão sob pressão do filho que foi produtor de sementes de milho no decorrer dos anos 1910. Em 1926, Wallace filhoque será ministro da agricultura de Roosevelt - funda a Pioneer com um capital de 7.600 dólares, hoje a maior empresa mundial de sementes. A Pioneer foi revendida há dois anos por 10 bilhões de dólares à empresa química-agrotóxica Du Pont. Que prova melhor de que o capital se reproduz e se multiplica a favor do selecionador, desde que a planta não possa fazê-lo na terra do camponês! Cada dólar investido em 1926 se reproduziu um milhão e quinhentas mil vezes em 70 anos. Não acredito que o milho se tenha reproduzido na terra dos camponeses norte-americanos de maneira tão exuberante! Assim, o termo "variedade híbrida de milho" permitiu desviar a atenção do fato de que enquanto os geneticistas discutem em vão as virtudes do hibridismo, cada dólar investido se reproduziu um milhão e quinhentas mil vezes.

De fato a biologia é minada pela guerra que faz, à sua revelia, contra o ser vivo. E a guerra exige utilizar um aparelho de propaganda sofisticado e, em particular, manipular as palavras, como Orwell bem observou.

Você poderia dar outros exemplos?

O termo OGM - Organismo Geneticamente Modificado. Todos os organismos vivos são "geneticamente" modificados a cada geração

15 Cf. R. Crabb, The hybrid corn makers, prophets of plenty (Rutgers University Press, 1947). 
uma vez que são fruto de uma mistura única de genes. "OGM" não tem portanto nenhum sentido específico. Mas permite maquiar a realidade. Os fabricantes de agrotóxicos, seus especialistas em relações públicas e seus biotécnicos (ou melhor, tecnoservos públicos e privados) - podem assim assegurar que eles perseguem de modo mais preciso, científico, seguro o que a humanidade sempre fez desde o começo da domesticação das plantas e dos animais, há cerca de dez mil anos. Durmam, vocês não precisam se preocupar, os especialistas estão vigilantes.

Mas se com efeito a humanidade continuamente modificou geneticamente as plantas e os animais, essa humanidade de camponeses reduziu-se agora aos dirigentes das firmas agrotóxicas. E as modificações genéticas consistem agora em fazer quimeras genéticas, construções artificiais que associam genes vindos de reinos, ordens, gêneros, espécies diferentes. A primeira patente referente a uma manipulação genética, a de Cohen e Boyer, dizia respeito a uma "quimera funcional”. Gene e função são substituíveis, como se viu. Mas fazer as pessoas comerem quimeras funcionais, ou quimeras genéticas, ou quimeras simplesmente é difícil. O termo OGM foi então imposto pelos industriais de acordo com os cientistas que sacrificaram a precisão do vocabulário à promoção. No INRA existem mesmo "cientistas" que julgaram que o termo OGM não era apetitoso o bastante e propuseram OGA - Organismos Geneticamente Aperfeiçoados [Organismes Génétiquement Améliorés]...

Hoje em dia, qualquer estudante de biologia sabe fazer quimeras genéticas. Essas quimeras são uma ruptura, termo utilizado pela Academia de Ciências que não tira daí as conseqüências. Entramos numa fase nova, na qual, como de costume, as técnicas têm décadas de avanço sobre os conhecimentos científicos. Michel Tibon Cornillot insiste nos riscos inauditos introduzidos pela industrialização de produtos de que não se sabe praticamente nada. Já falamos disso antes.

Você teria ainda outros exemplos?

Sim, vou dar um exemplo de que gosto muito porque a inversão da realidade atinge uma perfeição orwelliana. É o termo "privilégio do agricultor", que designa na novilíngua biotech a prática fundadora da agricultura, semear o grão colhido. É lógico que nunca os aristocratas nem os dirigentes das firmas agrotóxicas procuraram se beneficiar do privilégio de semear o que colhiam. Não, eles deixavam esse privilégio aos seus camponeses. O termo "privilégio do agricultor" permite inverter a realidade. Para fazer da reprodução seu privilégio, os fabricantes de agrotóxicos denunciam um inexistente privilégio do agricultor!

Esses fabricantes de agrotóxicos se apresentam como os industriais das "ciências da vida". Eles fabricam pesticidas, herbicidas, fungicidas, inseticidas e só Deus sabe que outros venenos acabados em “cida”. Sua técnica emblemática é o Terminator, uma técnica de esterilização do ser vivo. E eles se intitulam "industriais das ciências da vida". Suas biotecnologias são, na realidade, necrotecnologias.

Não será suficientemente dito que o sistema capitalista é mortífero. Todos os ecosistemas estão explodindo, os oceanos são 
lixeiras, a água está poluída, as terras esterilizadas, a biodiversidade agoniza. Evamos em frente.

Numa sessão em que você participou no Fórum Social Mundial o tema era a ciência reducionista. Você poderia falar um pouco disso?

O desenvolvimento formidável da biotecnologia de há 50 anos para cá passou pelos princípios reducionistas cartesianos. Primeiro princípio: é preciso dividir as coisas em partes cada vez menores e portanto simples (na aparência). Quanto menores, melhor podem ser manipuladas, melhor podem ser compreendidas. Segundo princípio: o todo não é senão a soma das partes. $\mathrm{O}$ mundo é uma espécie de relógio, de mecanismo do qual é preciso desmontar as peças. E o próprio homem é uma máquina. É o que diz La Métrie. Não podemos esquecer que o século xvir é fascinado pelos autômatos.

Enfatizou-se muito (exagerou-se seria talvez mais justo) o caráter sonolento da biologia até que a genética molecular a acordasse. Era talvez necessário sair das concepções holísticas que pesavam sobre a biologia até os anos 1940. Mas os limites desse mecanismo nos dois domínios gêmeos da biologia aplicada, a agricultura e a medicina, são agora evidentes. Na realidade nada funciona. Esse fracasso maciço é mascarado por uma sucessão de promessas extravagantes. Sabe-se hoje que os "OGM" não vão resolver a questão da fome e da desnutrição, e sim piorá-la e aprofundar o desastre ambiental da industrialização da agricultura e do ser vivo. Quanto às descobertas anunciadas aos quatro ventos de genes responsáveis pelo câncer, a esquizofrenia, o alcoolismo, o esporte (!), a obesidade, a homossexualidade, a inteligência, e quanto às promessas de curas milagrosas, elas contribuíram para lançar essa biologia e os cientistas que a praticam no ridículo e no descrédito.

O projeto da biologia moderna formulado por E. Schrödinger, ${ }^{\mathbf{1 6}}$ de reduzir o ser vivo a uma informação governando reações bioquímicas, quer dizer, reduzir o animado ao inanimado, é agora um fracasso. De um ponto de vista filosófico é um projeto mortífero. Ele permitiu avanços formidáveis, mas eles mostraram que o ser vivo era muito, muito mais complexo do que se acreditava, e que um novo paradigma tornou-se necessário.

O que se pode esperar das biotecnologias na agricultura?

Aculminação do processo histórico de industrialização e de privatização dos seres vivos, ou seja, um agravamento do desastre. $\mathrm{O}$ aumento da produção agrícola se fez a custos ambientais, econômicos, energéticos, humanos insustentáveis a longo prazo. Um exemplo: se em 1984, se tivesse decidido alimentar o conjunto do planeta, 5 bilhões de homens e mulheres, com as técnicas norte-americanas e segundo o modo de consumo norte-americano, o dos países industriais e da fração rica 
dos países do terceiro mundo, os recursos petrolíferos teriam se esgotado em 1996 segundo um cálculo de Pimentel, da Universidade de Cornell. E isso sem que uma gota fosse para o aquecimento e os transportes! O sistema agroindustrial utiliza entre 8 e 10 calorias fósseis para produzir uma caloria alimentar. O balanço deveria ser positivo, até mesmo muito positivo. Quem pode acreditar que a Índia ou a China terão um dia 2\% de sua população na agricultura sem um colapso dos agroecossistemas?

Este sistema não tem nenhuma possibilidade de durar do ponto de vista energético. Além disso, ele provoca uma destruição considerável. A FAO estima que quase um quarto das terras férteis foram esgotadas no século $\mathrm{xx}$ pelos métodos da agricultura industrial. ${ }^{\mathbf{1 7}}$ Os solos estão agonizando na maior parte dos países do mundo, na Europa, na França.

Ora, 80\% da biomassa da terra está, ao que parece, concentrada nos 30 primeiros centímetros do solo. Só seriam conhecidos entre 15 e $20 \%$ dos organismos dos solos. Os solos são seres vivos, são mesmo os seres vivos por excelência. Mas para a "agronomia" moderna, científica, reducionista os solos são suportes inertes. O sonho dessa "agronomia" moderna é a cultura hidropônica em estufa. Aí se controla tudo, menos o preço do petróleo! 3o centímetros de solo, sobre os 6.4,00 $\mathrm{km}$ do raio da Terra. Nós estamos instalados sobre uma película molecular de vida. Essa película nós a estamos destruindo. Os ciclos da água, do nitrogênio, do carbono estão ameaçados. O objetivo urgente de uma agronomia minimamente inteligente e moderna deveria ser restaurar a fertilidade natural dos solos e portanto abandonar a industrialização da agricultura.

O segundo caráter revolucionário dos "OGM" que são na realidade CQP, Clones (fica-se na lógica da uniformidade industrial) Quiméricos Patenteados - eu deveria ter enfatizado isso antes - é que eles são patenteados. Falar desse clones quiméricos sem falar da patente como fiz até aqui é considerar apenas um lado da mesma moeda. A patente permite que se proíba ao agricultor semear o grão colhido. A patente é o Terminator pela lei.

\section{Que fazer?}

O complexo genético-industrial e sua propaganda estrondosa se esforçam por esconder a existência de alternativas agronomicamente inteligentes, socialmente frutíferas, economicamente úteis, e ecologicamente duráveis. Sei que o Brasil e sua pesquisa agronômica estão mais avançados que a França nesse domínio e gostaria de saber mais sobre a experiência brasileira. Desculpem-me de dar um exemplo do Quênia e não do Brasil.

No Quênia o milho é atacado por um piralídeo asiático. É um inseto furador, como o piralídeo europeu. Ele é também parasitado por uma planta, a estriga. A estriga se instala

17 Cf. D. Pimentel e W. Dazhong, "Technological change in energy use in US agricultural production”, in C. R. Carroll, J. H.Vandermeer e P. M. Rosset (orgs.), Agroecology (Nova York, McGraw Hill, 1990). 
sobre as raízes do milho e desvia em seu proveito a fotossíntese. Essas duas pragas podem destruir um campo de milho.

Havia-se tentado lutar contra essas pragas pelos métodos da agricultura industrial, com inseticidas e herbicidas. Sem sucesso.

Nos anos 1980, cria-se um Centro Internacional de Pesquisa sobre a Fisiologia dos Insetos e a Ecologia (ICIPE) encarregado de criar métodos agro-ecológicos fundados no princípio push-pull, empurrar-puxar. A parte "push" consiste em semear ao mesmo tempo que o milho uma leguminosa, Desmodium, cujo cheiro é desagradável para o piralídeo. A borboleta do piralídeo tem assim tendência a sair do campo de milho, tanto mais facilmente que - a parte "pull" - cercou-se o campo de milho com uma planta forrageira de excelente qualidade, a erva de elefante - Napier grass em inglês. O piralídeo põe ovos sobre essa erva de elefante que lhe agrada e, depois dos primeiros estágios de desenvolvimento, a lagarta entra no interior do caule onde se torna prisioneira da mucilagem produzida pela planta. A maioria das lagartas são assim destruídas. Desmodium tem, além disso, três efeitos benéficos. Ela age como herbicida da estriga. Na presença do Desmodium a estriga não cresce. Desmodium é uma leguminosa, como dissemos. As leguminosas fixam o nitrogênio do ar enquanto as gramíneas, em particular o milho, são gulosas por nitrogênio. Você põe assim ao pé do milho uma fábrica biológica que lhe fornece o nitrogênio de que ele precisa. E por fim Desmodium protege o solo dos raios solares e da erosão pluvial. Num vilarejo onde essa técnica foi utilizada o número de vacas leiteiras passou em alguns anos de 4 para 200. Além do melhoramento da alimentação dos habitantes do vilarejo, essas vacas fornecem adubo e contribuem para manter a fertilidade dos solos fornecendo-lhes uma matéria orgânica preciosa.

Este é um soberbo trabalho científico que associou pesquisadores e camponeses. Ele garante ao camponês colheitas confiáveis, abundantes, sem compra de adubos, nem de herbicidas, nem de inseticidas. O bem-estar dos camponeses cresce mas... o PIB e os lucros diminuem. Logo, do ponto de vista que tudo domina no mundo, o da economia, da expansão ilimitada do sistema mercantil, é catastrófico. O Estado vive das taxas de importação sobre produtos como herbicidas, pesticidas ou adubos. Os fabricantes de agrotóxicos fizeram uma campanha de descrédito do ICIPE alegando que ele queria privar os agricultores africanos do acesso às tecnologias mais modernas - aos "OGM". Há três anos o Quênia cedeu. A Monsanto utilizou uma pesquisadora queniana, uma antiga empregada, que percorreu o mundo para dizer que os "OGM" iam salvar a África da fome.

O exemplo queniano é uma parábola da lógica científica dominante. Camponeses e agrônomos em seu trabalho quotidiano com a natureza elaboram com meios fracos uma alternativa criando zonas de liberdade, de autonomia. Mas tais alternativas não interessam, ou interessam muito pouco, à pesquisa de Estado porque elas não são uma fonte de lucro. A dinâmica tecnocientífica que anima - à sua revelia, mas isso pouco importa - essa pesquisa de Estado, mentirosamente dita "pública", é a de criar novas mercadorias e portanto novas fontes de lucro, e simultânea 
e logicamente destruir a autonomia das comunidades rurais e os últimos espaços de liberdade.

Constata-se mais uma vez a importância do vocabulário. Um pesquisador de Estado não é um pesquisador público. Ele se torna pesquisador público quando toma consciência de seu papel no sistema, quando se torna capaz de dissipar a cortina de fumaça ideológica que lhe esconde esse papel. Muito poucos têm oportunidade de fazê-lo. Eu tive essa oportunidade na minha carreira.

Em suma, em nosso mundo capitalista estatal, a autonomia e a liberdade das pessoas e dos grupos são uma ameaça. As tecnociências são o instrumento por excelência para submetê-los. A pesquisa de Estado, enquanto instituição, jamais investirá espontaneamente em alternativas não-comerciais. Será preciso uma pressão muito forte da opinião pública em face do desastre agroecológico para forçá-la a agir a favor do bem-estar público, quer dizer, contra a extensão do sistema mercantil.

Qual é a situação da agricultura na França?

Calamitosa. A poluição das águas de superfície e dos lençóis freáticos pelos pesticidas e os adubos é geral, em particular na Bretanha onde até mesmo o mar está poluído pela proliferação de algas verdes devidas aos nitratos da criação industrial de porcos, aves e bovinos. Os solos estão degradados em particular nas regiões cerealistas de onde os animais desapareceram, e com eles a matéria orgânica, quer dizer, a vida dos solos. A erosão é geral. As catástrofes se sucedem a um ritmo rápido, inundações, seca, mas são poucos os que vêem que elas são provocadas, em grande parte, pela degradação dos agrosistemas. E, por fim, o desenvolvimento da cultura do milho "híbrido", sob a pressão dos produtores de sementes, fora das zonas onde os camponeses o tinham sabiamente isolado, constitui uma catástrofe ecológica de grande amplitude. A cultura do milho implica desperdiçar quantidades maciças de água para a irrigação, ela deixa os solos nus no inverno e sujeitos à erosão. O destruidor de ervas "daninhas" do milho, a atrazina, é talvez o maior poluente das águas. Quanto aos agricultores, apesar de subvenções maciças (açambarcadas pelos maiores), seu número não pára de diminuir e um quarto dentre eles vive na miséria.

Em face desse desastre ecológico, a pesquisa de Estado propõe continuar avançando, propõe os clones quiméricos patenteados! Há três anos, pela primeira vez em mais de 50 anos de existência, o INRA (Institut National de la Recherche Agronomique) se interessou pela agricultura biológica. Pessoalmente não desejo que ele se ocupe com isso enquanto instituição, pois sua cultura, sua razão de ser, sua missão histórica era "modernizar" a agricultura, quer dizer, erradicar o campesinato para pôr em seu lugar o sistema agroindustrial. $\mathrm{O}$ que foi feito sem cautela em uma geração com as conseqüências que vemos.

Entretanto é preciso distinguir o INRA enquanto instituição de Estado dos pesquisadores do INRA. Um certo número dentre eles dão-se conta a título individual do papel que a instituição os faz representar. Mas para que eles possam se fazer ouvir no interior da 
instituição será preciso uma pressão formidável do exterior e, é claro, da realidade. Neste momento, a consciência de que a pesquisa de Estado está a serviço do Estado e de que o Estado não serve ao interesse público, mas aos interesses econômicos dominantes - as transnacionais -, permanece vaga. Para se tornar um pesquisador público, um pesquisador de Estado deve tornar-se um dissidente. O fato de chamar essa pesquisa de Estado de pesquisa "pública" permite à maioria tranqüilizar-se sem muito custo a respeito do que faz.

Ademais essa não é uma questão de direita ou de esquerda. A "esquerda" (o que se designa com esse nome) talvez seja mais vítima das ilusões progressistas e cientificistas que a direita. É preciso acrescentar também que a cultura reducionista cartesiana que domina o pensamento científico na França não prepara os pesquisadores para compreender que uma planta é uma coisa diferente de um monte de genes, e que ela cresce num campo e não in silico, num computador, nem que o campo faz parte de um sistema social de economia política que determina, como vimos, até mesmo o conteúdo das "verdades" científicas.

Vocêpoderia falar um pouco do dinheiro investido na pesquisa em biotecnologia e não em agricultura interativa, por exemplo?

Sim... Os problemas das chamadas ervas "daninhas", dos destruidores, das doenças etc. são largamente criados pela industrialização da agricultura, pela pesquisa da uniformidade industrial, das economias de escala, da produtividade a curto prazo. Nossa agricultura científica é uma agricultura "cow-boy". Se alguma coisa se mexe, atira-se sem nem mesmo refletir. Os pesticidas ilustram esse grau zero da reflexão biológica. Um destruidor aparece - freqüentemente porque os herbicidas deixando os campos perfeitamente "limpos" suprimiram seu habitat. Trata-se com inseticida. Tudo vai bem até que o destruidor se torne resistente. Aumentam-se então as quantidades utilizadas, e quando isso não funciona mais, introduz-se um novo pesticida numa corrida para a frente cada vez mais rápida. Para os fabricantes de agrotóxicos é perfeito. $\mathrm{O}$ número de insetos resistentes aos inseticidas passou em 40 anos de algumas dezenas a várias centenas.

O objetivo de uma agronomia inteligente e moderna seria definir para cada espécie, inclusive os parasitas, inclusive os destruidores, seu lugar, seu nicho no ecossistema cultivado, de modo que eles nos chateiem o menos possível. Para isso é preciso voltar as costas à industrialização do ser vivo. Utilizando a diversidade do mundo vivo é que os problemas postos pelos destruidores e pelas doenças serão, não eliminados - é biologicamente idiota pensar assim -, mas reduzidos a uma dimensão suportável. A clonagem dos mamíferos tem contudo um interesse: tornar evidente a destruição brutal e irreversível da biodiversidade. Quando é que nós tomaremos consciência que se passa o mesmo com as plantas?

No entanto segue-se o caminho oposto já há 20 anos com o triunfo da genética. Sonha-se com a arma absoluta, com a bala mágica. A mentalidade "cow-boy" continua sua 
destruição. Contudo, 20 anos de investimentos maciços nas biotechs em busca da arma absoluta nada deram a não ser plantas pesticidas. O fracasso é maciço e evidente e mesmo os efeitos triunfais da propaganda não podem esconder essa realidade. Se as mesmas somas tivessem sido investidas num procedimento científico agroecológico acompanhado por uma transformação das políticas agrícolas, nosso bem-estar-medido por critérios de alimentação, de saúde pública, de meio ambiente, de empregos úteis - teria aumentado consideravelmente. Mas o PIB e os lucros teriam diminuído. O problema está sempre aí.

Existe um desperdício considerável de recursos ligado à ilusão reducionista de que quando tivermos compreendido os genes, teremos compreendido o mundo, inclusive o mundo social. Esta concepção extremista do reducionismo desemboca na sociobiologia. Mas entre o gene e uma planta cultivada existe toda uma série de níveis, cada um deles com seu próprio método de estudo, o genoma, a célula, o órgão, o organismo, o ecossistema, por fim o sistema social. O que se passa na escala molecular não tem pertinência, salvo exceção, para compreender os níveis superiores. Desde o começo da genética, Johanssen havia distinguido o genótipo (os genes) do fenótipo (o organismo), infelizmente essa distinção embora clássica foi esquecida pela maioria dos biólogos que se pretendem modernos.

Sabemos que além da agricultura você tem se interessado também pela indústria farmacêutica...
Fui levado a me interessar pela indústria farmacêutica por duas razões. Por um lado, o projeto inicial das assim chamadas "ciências da vida" [sciences de la vie] era unificar num cartel de um pequeno grupo de empresas tudo o que diz respeito à biologia aplicada, ou seja, aos dois domínios gêmeos da agricultura e da saúde, uma vez que ambos se reduziam ao DNA. Este projeto foi abandonado por causa da rejeição européia aos "OGM". Os laboratórios livraram-se dos OGM e dos agrotóxicos para evitar "contaminar" seus produtos farmacêuticos, imensamente lucrativos. Convinha portanto atentar para o setor farmacêutico que desempenhou um papel impulsionador pelo menos provisoriamente.

Por outro lado, um exame mesmo superficial do setor farmacêutico mostra que o que aí ocorre é a imagem num espelho do que observei na agricultura. $\mathrm{Na}$ agricultura, o selecionador deve lutar contra a concorrência desleal das plantas e animais que se reproduzem na terra do agricultor. No domínio da saúde, a lógica econômica exige que os laboratórios lutem contra essa injustiça que cometem as pessoas de boa saúde. Jules Romains na peça Knock escreveu uma sátira sobre este tema. O objetivo de um laboratório é o de nos tornar doentes, pelo menos potencialmente. Como estender o mercado da doença a todas as pessoas saudáveis? Este é o problema gerencial de um diretor de laboratório, que tem a obrigação de maximizar os lucros de sua empresa.

A genômica fornece a resposta. Trata-se da decifração do genoma humano. Pois todos nós somos portadores de "predisposições 
genéticas" a umas cinqüenta moléstias. Em suma, temos nossas pequenas fraquezas e somos todos diferentes face a uma doença qualquer. Se não há excesso de estresse em nossa vida, se nossa saúde não é usada prematuramente, se evitarmos viver em ambientes poluídos, quer dizer, se evitarmos Coca-Cola, Mc Donald's e os pesticidas da Monsanto, não sofreremos dessas moléstias potenciais.

Em 2010-2015 cada indivíduo terá seu genoma num cartão magnético. Poderemos então prognosticar as moléstias que nos ameaçam mesmo antes da concepção! Será necessário então tomar tal medicamento, ou comer tal alicamento, ou nutricamento. Medicalizar a alimentação é mais rentável que vender alimentos saudáveis, cultivados adequadamente e em lugar próximo do lugar de consumo. Em outras palavras, é mais fácil transformar pessoas saudáveis em doentes potenciais que transformar os doentes em pessoas saudáveis. E, sobretudo, é mais lucrativo. Reside aí a dinâmica de fundo que determina as orientações da pesquisa médica.

Vamos agora aos fatos. A indústria farmacêutica encontra-se em vias de se tornar o principal setor econômico do mundo capitalista, em termos de faturamento. É também o setor mais lucrativo com uma taxa de lucro sobre vendas de aproximadamente 17 ou $18 \%$, de acordo com a revista Fortune. A indústria automobilística se contenta com $2,7 \%$. E, contudo, os automóveis funcionam, o que não se pode dizer da maior parte dos medicamentos. Do ponto de vista do capital, é o setor do futuro, ainda mais dado que a média de idade da população nos países ricos é cada vez mais alta.
Enfim, os laboratórios não são diferentes dos mercadores de sabão em pó. Eles aplicam um terço de seu faturamento em marketing, mas em vez de dirigir-se diretamente ao consumidor, eles procuram controlar os "receitadores", ou seja, os médicos. Ao contrário da imagem que tais benfeitores da humanidade desejam passar, segundo a qual investiriam somas consideráveis em pesquisas arriscadas do ponto de vista do retorno, eles investem apenas de 10 a $12 \%$ de seu faturamento em pesquisa. E a própria pesquisa é orientada para o mercado, sendo a maior parte do faturamento destinado à defesa das patentes e aos mercados de moléculas. Por exemplo, os laboratórios preferem investir em moléstias crônicas, ditas "da civilização", em que o retorno é grande e de longa duração, que em antibióticos utilizados de forma pontual.

Essa indústria promove de uma só vez o superconsumo de remédios nos países centrais e nega aos países do terceiro mundo o acesso aos medicamentos indispensáveis. Nos primeiros, tal superconsumo faz centenas de milhares de vítimas. Nos segundos, os mortos se contam aos milhões. Uma empresa como a Novartis consagra 50 milhões de francos ao marketing, uma soma suficiente para prover a África de medicamentos básicos.

A corrupção é sistêmica. Acabo de ler no New York Times de ontem que os cancerologistas estadunidenses obtêm a maior parte de seus rendimentos da venda a seus pacientes de medicamentos contra o câncer. Eles são os únicos clínicos isentos da proibição de vender os medicamentos que prescrevem. $\mathrm{O}$ Congresso deve rever tal isenção. 
O Brasil e a Índia produzem genéricos para o tratamento da Aids 4,0 vezes mais baratos que o preço exigido pelos laboratórios. Uma queda de braço opõe os países centrais aos países do terceiro mundo sobre a questão das patentes desses medicamentos ou, mais precisamente, dos limites a serem impostos sobre tais patentes. É bom que os brasileiros saibam que não estão sós, e que a opinião pública nos países centrais, em particular nos Estados Unidos, está exasperada pelas predações da indústria farmacêutica. Isso significa que há um espaço de luta a ser aberto para eliminar as patentes de medicamentos. Há uma convergência de interesses dos povos do mundo inteiro contra uma indústria de comportamento criminoso. E mesmo os salários obscenos da indústria farmacêutica não são suficientes para neutralizar a consciência de seus dirigentes.

No Brasil, vocês têm uma longa experiência da predação dessa indústria. Durante a segunda guerra mundial, enquanto os países centrais estavam ocupados fazendo a guerra, o Brasil desenvolveu sua produção nacional de medicamentos a partir das farmácias de hospital. Terminada a guerra, os laboratórios exigiram que o governo brasileiro não protegesse essa indústria nascente, que foi assim liqüidada.

Um próximo Fórum Social Mundial poderia juntar informação sobre a predação da indústria farmacêutica tanto nos países centrais como no terceiro mundo. Uma espécie de tribunal Russell poderia instruir o processo divulgando informações precisas e detalhadas sobre a história, as práticas, os métodos, o marketing, a pesquisa (ou a esterilidade da pesquisa $)^{\mathbf{1 8}}$ e sobre os perigos a que submete a saúde dos povos. Trata-se de abrir um espaço político que permita reconstruir um sistema de saúde que estaria a serviço da população, em particular através da prevenção, e não a serviço do lucro. Tecnicamente, isso é bem simples de fazer. É preciso separar a pesquisa, que deve tornar-se pública (e assim, adeus às patentes), e a produção. Politicamente, o caminho será longo.

\section{Isabel LOUREIRO}

Professora Aposentada do Departamento de Filosofia da Universidade Estadual Paulista - Campus Marília.

Marcos Barbosa de Oliveira

Professor Associado do Departamento de Filosofia da Educação e Ciências da Educação da Universidade de São Paulo. mbdolive@usp.br

18 Cf. P. Pigarre, Le grand secret de l'industie pharmaceutique (Paris, 2003). 